\title{
Report on FY 2021 Creep, Fatigue, and Creep-Fatigue Testing of Alloy 709 Base Metal at ORNL
}

Approved for public release. OAK RIDGE NATIONAL LABORATOR MANAGED BY UT BATTELLE

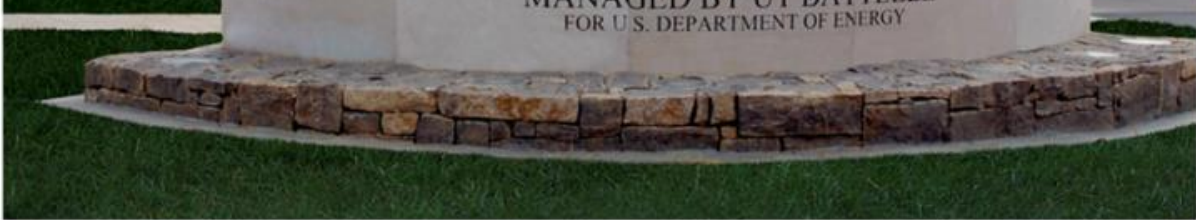

\section{Distribution is unlimited.}

Yanli Wang

Peijun Hou

T.-L. Sham

August 2021 


\title{
DOCUMENT AVAILABILITY
}

Reports produced after January 1, 1996, are generally available free via US Department of Energy (DOE) SciTech Connect.

Website www.osti.gov

Reports produced before January 1, 1996, may be purchased by members of the public from the following source:

\author{
National Technical Information Service \\ 5285 Port Royal Road \\ Springfield, VA 22161 \\ Telephone 703-605-6000 (1-800-553-6847) \\ TDD 703-487-4639 \\ Fax 703-605-6900 \\ E-mail info@ntis.gov \\ Website http://classic.ntis.gov/
}

Reports are available to DOE employees, DOE contractors, Energy Technology Data Exchange representatives, and International Nuclear Information System representatives from the following source:

Office of Scientific and Technical Information

PO Box 62

Oak Ridge, TN 37831

Telephone 865-576-8401

Fax 865-576-5728

E-mail reports@osti.gov

Website http://www.osti.gov/contact.html

This report was prepared as an account of work sponsored by an agency of the United States Government. Neither the United States Government nor any agency thereof, nor any of their employees, makes any warranty, express or implied, or assumes any legal liability or responsibility for the accuracy, completeness, or usefulness of any information, apparatus, product, or process disclosed, or represents that its use would not infringe privately owned rights. Reference herein to any specific commercial product, process, or service by trade name, trademark, manufacturer, or otherwise, does not necessarily constitute or imply its endorsement, recommendation, or favoring by the United States Government or any agency thereof. The views and opinions of authors expressed herein do not necessarily state or reflect those of the United States Government or any agency thereof. 
Materials Science and Technology Division

\title{
REPORT ON FY 2021 CREEP, FATIGUE, AND CREEP-FATIGUE TESTING OF ALLOY 709 BASE METAL AT ORNL
}

\author{
Yanli Wang \\ Peijun Hou* \\ T.-L. Sham ${ }^{\dagger}$
}

* Imtech Corporation, Knoxville

$\dagger$ †daho National Laboratory

Date Published: August 2021

Prepared by

OAK RIDGE NATIONAL LABORATORY

Oak Ridge, TN 37831-6283

managed by

UT-BATTELLE, LLC

for the

US DEPARTMENT OF ENERGY

under contract DE-AC05-00OR22725 



\section{CONTENTS}

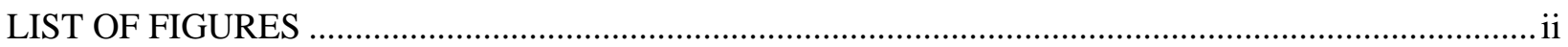

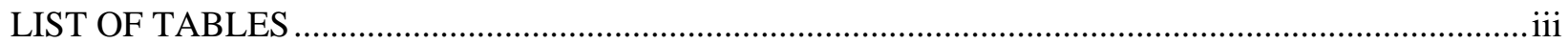

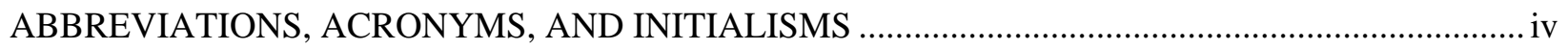

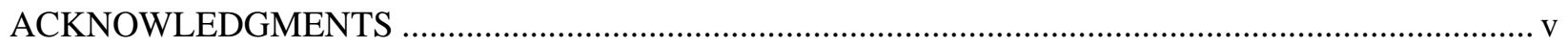

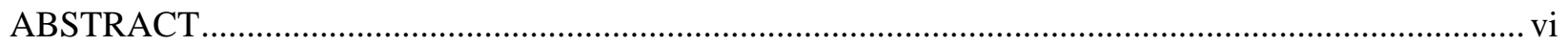

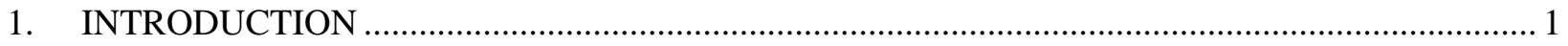

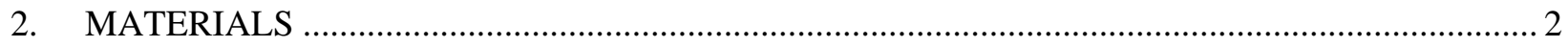

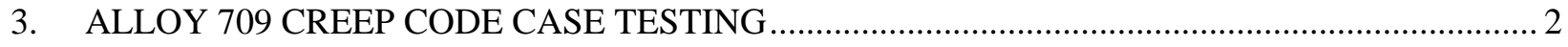

3.1 ALLOY 709 CREEP CODE CASE TESTING PLAN AND STATUS at ORNL ................... 2

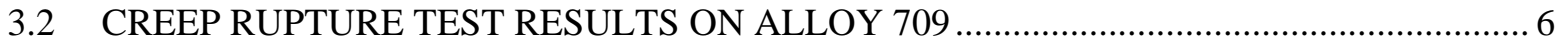

4. FATIGUE AND CREEP-FATIGUE CODE CASE TESTING ON ALLOY $709 \ldots \ldots \ldots \ldots \ldots \ldots \ldots \ldots \ldots . . . . \ldots \ldots$

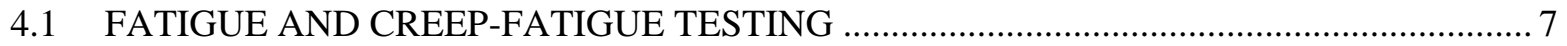

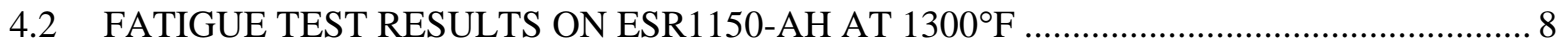

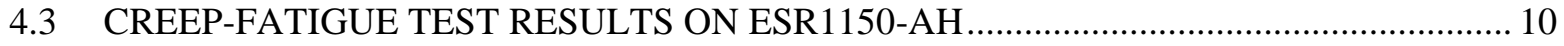

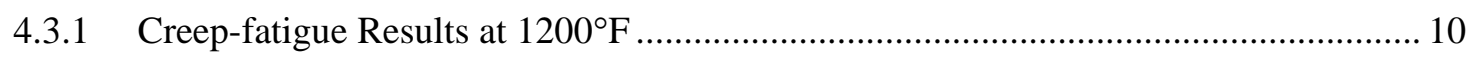

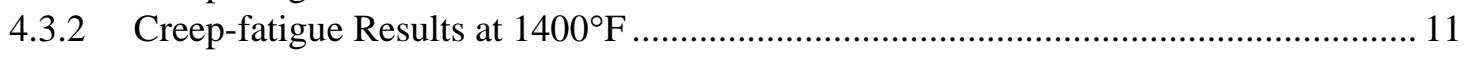

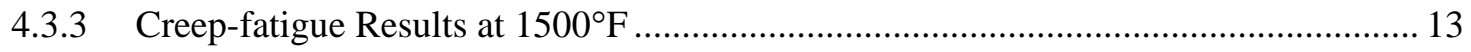

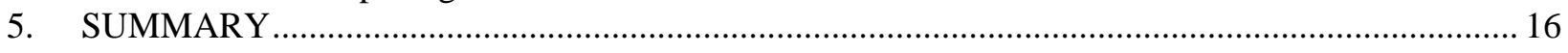

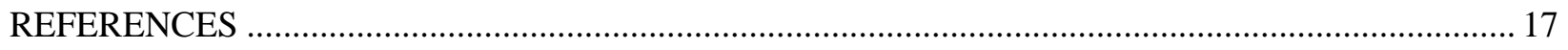




\section{LIST OF FIGURES}

Fig. 1. Creep specimen geometry for Alloy 709 Code Case testing at ORNL. ...................................... 3

Fig. 2. Comparison of the ESR 1100, AOD1100, ESR1150, and ESR1150-AH creep rupture data with data for Nippon Steel NF709 on the LMP-stress plot.

Fig. 3. Standard fatigue and creep-fatigue specimen geometry for Alloy 709 Code Case testing at

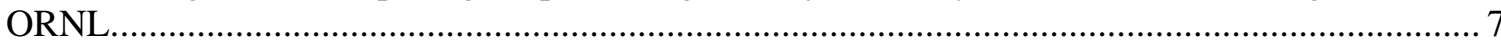

Fig. 4. Strain-controlled fatigue (a) and creep-fatigue (b) loading profile for one cycle.

Fig. 5. Maximum and minimum stresses of fatigue tests on Alloy 709 ESR 1150-AH (heat number 58776-3RBC) at strain ranges of $1.0 \%(\mathrm{a}), 0.6 \%(\mathrm{~b})$, and two tests at $0.3 \%(\mathrm{c}, \mathrm{d})$ at $1300^{\circ} \mathrm{F}$.

Fig. 6. Maximum and minimum stresses as a function of applied cycles (a, d, g); representative hysteresis loops (b, e, h); and normalized stress relaxation curves (c, f, i) for CF at $1.0 \%$ strain range and tension-hold times of $3600 \mathrm{~s}, 1800 \mathrm{~s}$, and $600 \mathrm{~s}$ at $1200^{\circ} \mathrm{F}$.

Fig. 7. Comparison of the stress relaxation curves during tension-hold segments at mid-life cycles between $600 \mathrm{~s}, 1800 \mathrm{~s}$, and $3600 \mathrm{~s}$ hold times at a $1.0 \%$ strain range at $1200^{\circ} \mathrm{F}$.

Fig. 8. Maximum and minimum stresses as a function of applied cycles (a,d), representative hysteresis loops (b, e), and normalized stress relaxation curves (c, f) for $\mathrm{CF}$ at a $0.6 \%$ strain range and tension-hold times of $1800 \mathrm{~s}$ and $600 \mathrm{~s}$ at $1400^{\circ} \mathrm{F}$.

Fig. 9. Maximum and minimum stresses as a function of applied cycles (a), representative hysteresis loops (b), and normalized stress relaxation curves (c) for $\mathrm{CF}$ at a $1.0 \%$ strain range and a tension-hold time of $600 \mathrm{~s}$ at $1400^{\circ} \mathrm{F}$

Fig. 10. Fatigue and creep-fatigue data at $1400^{\circ} \mathrm{F}$.

Fig. 11. Maximum and minimum stresses as a function of applied cycles (a, d, g), representative hysteresis loops (b, e, h), and normalized stress relaxation curves (c, f, i) for $\mathrm{CF}$ at a $1.0 \%$ strain range and tension-hold times of $3600 \mathrm{~s}, 1800 \mathrm{~s}$, and $600 \mathrm{~s}$ at $1500^{\circ} \mathrm{F}$.

Fig. 12. Maximum and minimum stresses as a function of applied cycles (a, d, g), representative hysteresis loops (b, e, h), and normalized stress relaxation curves (c, f, (i) for CF at a $0.6 \%$ strain range and tension-hold times of $3600 \mathrm{~s}, 1800 \mathrm{~s}$, and $600 \mathrm{~s}$ at $1500^{\circ} \mathrm{F}$.

Fig. 13. Comparison of stress relaxation curves during tension-hold at mid-life cycles for CF tests at strain ranges of $1.0 \%$ (a) and $0.6 \%$ (b) at $1500^{\circ} \mathrm{F}$.

Fig. 14. Maximum and minimum stresses as a function of applied cycles (a) and normalized stress relaxation curves (b) for $\mathrm{CF}$ at a $0.3 \%$ strain range and a tension-hold time of $600 \mathrm{~s}$ at $1500^{\circ} \mathrm{F}$....... 


\section{LIST OF TABLES}

Table 1. Chemical compositions of Alloy 709 with master heat number 58776 (wt \%), ........................ 2

Table 2. Creep Code Case testing matrix on Alloy 709 (heat number 58776). ........................................ 4

Table 3. FY 2021 ongoing creep Code Case testing on ESR1100 and AOD1100 at ORNL..................... 4

Table 4. FY 2021 creep Code Case testing status on ESR1150-AH at ORNL ......................................... 5

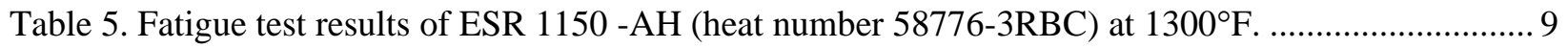

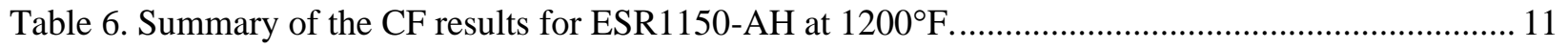

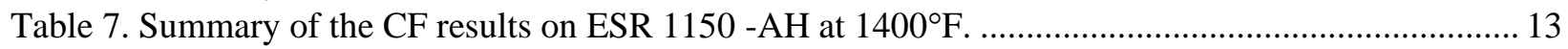

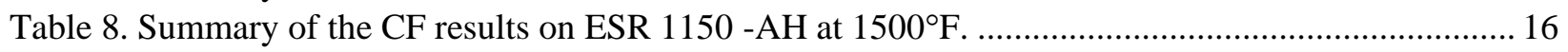




\section{ABBREVIATIONS, ACRONYMS, AND INITIALISMS}

$\begin{array}{ll}\text { ANL } & \begin{array}{l}\text { Argonne National Laboratory } \\ \text { argon-oxygen-decarburization }\end{array} \\ \text { AOD } & \text { Advanced Reactor Technologies } \\ \text { ART } & \text { American Society of Mechanical Engineers } \\ \text { ASME } & \text { American Society for Testing and Materials } \\ \text { ASTM } & \text { creep-fatigue } \\ \text { CF } & \text { Department of Energy } \\ \text { DOE } & \text { electroslag remelt } \\ \text { ESR } & \text { Idaho National Laboratory } \\ \text { INL } & \text { Larson-Miller Parameter } \\ \text { LMP } & \text { Office of Nuclear Energy } \\ \text { NE } & \text { Oak Ridge National Laboratory } \\ \text { ORNL } & \text { solution-annealing or solution-annealed } \\ \text { SA } & \text { sodium fast reactor }\end{array}$




\section{ACKNOWLEDGMENTS}

This research was sponsored by the US Department of Energy (DOE), under contract DE-AC0500OR22725 with Oak Ridge National Laboratory (ORNL), managed and operated by UT-Battelle LLC, and under Contract No. DE-AC07-05ID14517 with Idaho National Laboratory, managed and operated by Battelle Energy Alliance. Programmatic direction was provided by the Office of Nuclear Reactor Deployment of the DOE Office of Nuclear Energy.

The authors gratefully acknowledge the support provided by Sue Lesica, Federal Lead, Advanced Materials, Advanced Reactor Technologies (ART) Program; Brian Robinson, Federal Manager, ART Fast Reactors (FR) Campaign; and Robert Hill of Argonne National Laboratory (ANL), National Technical Director, ART FR Campaign.

Helpful discussions with Ryann Rupp of the Idaho National Laboratory and Xuan Zhang of ANL are gratefully acknowledged. The authors also wish to thank ORNL staff members C. Shane Hawkins, Kelsey Hedrick, and Christina Austin for their technical support in carrying out the experiments. The time spent by Lianshan Lin, Jian Chen, and Edgar Lara-Curzio of ORNL reviewing this report is acknowledged. 


\begin{abstract}
The testing activities and research in support of ASME Code qualification of Alloy 709, an advanced austenitic steel, are being carried out at Oak Ridge National Laboratory (ORNL), Argonne National Laboratory, and Idaho National Laboratory. ORNL has been tasked to carry out a subset of the Code Case testing for creep rupture, fatigue and creep-fatigue.

The focus of the FY 2021 Code Case testing on Alloy 709 base metal at ORNL includes (1) continuing the long-term creep rupture testing on ESR1100 and AOD1100; (2) adding ESR1150-AH to the creep Code Case testing matrix; and (3) continuing fatigue and creep-fatigue Code Case testing on ESR1150AH. This report summarizes the status and the preliminary test results of FY 2021 planned Code Case testing at ORNL.
\end{abstract}




\section{INTRODUCTION}

Nuclear power contributes significantly to meeting US energy, economic, environmental, and national security needs. The sodium fast reactor (SFR) is a leading candidate for recycling of used fuel to close the fuel cycle and for power generation. While SFR technology is relatively mature, there must be improvements in its capital cost and economic return before the private sector invests in large-scale, commercial deployment of SFRs. Advanced materials can have a significant impact on the flexibility, safety, and economics of future SFRs because innovative designs and design simplifications could be possible using materials with enhanced mechanical properties. Improved materials performance also impacts safety through improved reliability and greater design margins, and improved material reliability could result in reduced downtime. The objective of the Advanced Materials Development activities of the Advanced Reactor Technologies (ART) Program for the US Department of Energy, Office of Nuclear Energy is to provide the technical basis needed to support the regulatory requirements for structural materials for advanced reactors that could be deployed in the near-term to mid-term by the US nuclear industry.

Because of significant enhancements in the mechanical properties of the austenitic stainless steel Alloy 709 relative to $316 \mathrm{H}$ stainless steel, a reference construction material for SFR systems, code qualification of Alloy 709 was recommended in FY 2014. A comprehensive plan was established in FY 2015 for the development of a 500,000 h, $760^{\circ} \mathrm{C}$ ASME Code Case and the resolution of structural integrity issues identified by the Nuclear Regulatory Commission. The maximum use temperature of $760^{\circ} \mathrm{C}$ for the Alloy 709 Code Case has also drawn interest from molten salt reactor vendors and fluoride salt-cooled hightemperature reactor developers. Completion of the Alloy 709 Code Case will allow US reactor vendors to decrease capital costs, expand design envelopes, and increase safety margins in the deployment of SFRs and other reactor concepts. Doing so will boost the competitiveness of the US advanced reactor sector, create high-paying jobs, and increase economic growth.

The data package for code qualification must contain a minimum of three commercial heats which represent the anticipated compositional ranges. In FY 2017, in collaboration with material vendor G.O. Carlson Inc. of Pennsylvania, the ART program successfully scaled up the production of Alloy 709 from a laboratory heat of $500 \mathrm{lb}$ to a commercial heat of 45,000 lb. The master heat of Alloy 709, heat number 58776, was processed, hot-rolled into plates, and solution-annealed (SA). The fabrication procedures and room-temperature characterization of heat 58776 Alloy 709 plates are summarized in Natesan et al. (2017). Meanwhile, creep-testing frames at Oak Ridge National Laboratory (ORNL) were upgraded or refurbished, and some new creep frames were procured at the Idaho National Laboratory (INL) and the Argonne National Laboratory (ANL), to support the generation of creep rupture data for the Alloy 709 Code Case. The Code Case test effort for the comprehensive creep test matrix developed to support the preliminary, 100,000 h, 300,000 h, and 500,000 h Alloy 709 Code Cases was split among Argonne, INL, and ORNL. In FY 2018, long-term creep tests were initiated at ORNL for plates produced by argonoxygen-decarburization (AOD) and SA at $1100^{\circ} \mathrm{C}$ (Wang et al. 2018). In FY 2019, electroslag remelted (ESR) with SA at $1100^{\circ} \mathrm{C}$ was added to the intermediate and long-term testing effort (Wang and Sham 2019).

For high-temperature components, a material's ability to withstand combined cyclic loading and creep deformation is expected to be a critical aspect of its application. Zhang, Sham and Young (2019) have developed a heat treatment protocol consisting of $775^{\circ} \mathrm{C}$ for $10 \mathrm{~h}$ applied to as-annealed Alloy 709 to enhance its creep-fatigue resistance. Fatigue and creep-fatigue (CF) testing by McMurtrey and Rupp (2019) showed significant improvement in the CF life of the heat-treated Alloy 709 over that in the asannealed condition. The precipitates introduced in the microstructure by heat treatment played an important role in the enhanced CF performance (Zhang and Sham 2019). To achieve a balanced creep and 
CF performance, heat-treated ESR with SA at $1150^{\circ} \mathrm{C}$ was added to the Code Case test matrix in FY 2020.

In FY 2021, researchers at INL led the effort in procuring the second commercial heat of Alloy 709 from Allegheny Technologies Incorporated (ATI). Flat rolled plates with the master heat number of 529900 and total weight of 40,500 lb were successfully delivered. At the time of writing of this report, ORNL is in the process of sectioning these plates to support baseline characterization and Code Case testing at the three labs. Meanwhile, two servo-hydraulic machines are being upgraded to add to the high-temperature testing capability in support of CF code case testing with long hold times at ORNL.

This report documents the status and results of the planned FY 2021 creep, fatigue, and CF Code Case testing on Alloy 709 base metal (heat number 58776) at ORNL.

\section{MATERIALS}

The chemical compositions of Alloy 709 with the heat number 58776 are listed in Table 1 . The ESR plates had a sub-heat number of 58776-3R; the plates with SA at $1100^{\circ} \mathrm{C}(\mathrm{ESR} 1100)$ had a lot ID of 58776-3RBB, and those with SA at $1150^{\circ} \mathrm{C}$ (ESR1150) had a lot ID of 58776-3RBC. The nominal thickness of the ESR plates was $28.5 \mathrm{~mm}$. The Alloy 709 plates produced by AOD had a sub-heat number of 58776-4 and those with SA at $1100^{\circ} \mathrm{C}$ (AOD1100) had a lot ID of 58776-4B. The nominal thickness of the AOD plates was $30 \mathrm{~mm}$.

For comparison, the specifications for the chemical requirements of Nippon Steel NF709, TP310MoCbN, seamless tubing, with a UNS number of S31025 in ASME SA-213 (ASME 2019a) are also listed in Table 1. Alloy 709 with heat number 58776 in this study met the specified NF709 chemical requirements.

An additional heat treatment of the ESR plate with SA at $1150^{\circ} \mathrm{C}$ was performed to ensure a balanced creep and CF performance. The heat treatment was at $775^{\circ} \mathrm{C}$ for $10 \mathrm{~h}$ in air, followed by air cooling. The heat-treated ESR1150 plates are designated as "ESR1150-AH" in this report.

Table 1. Chemical compositions of Alloy 709 with master heat number 58776 (wt \%).

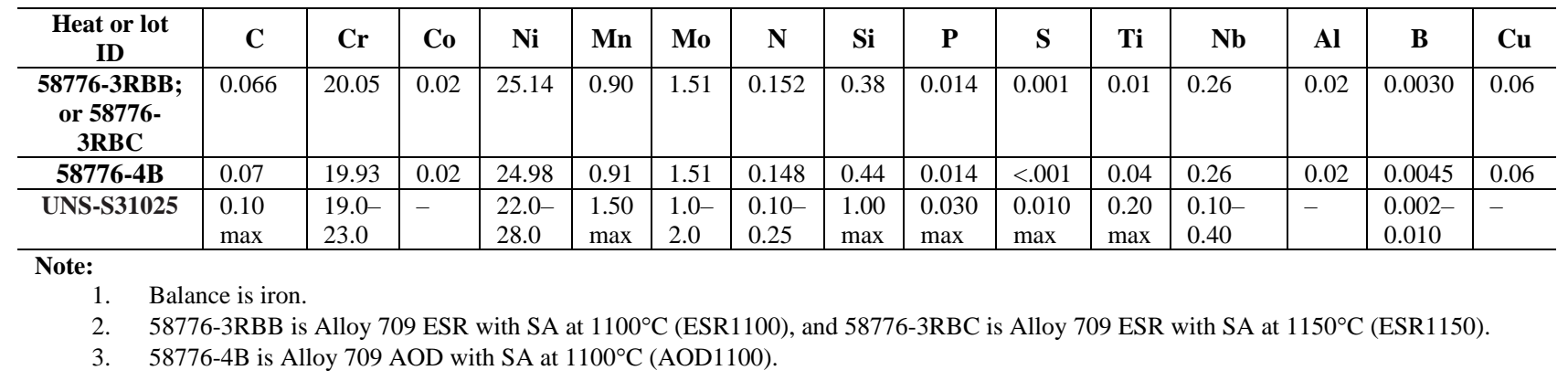

\section{ALLOY 709 CREEP CODE CASE TESTING}

\subsection{ALLOY 709 CREEP CODE CASE TESTING PLAN AND STATUS AT ORNL}

A comprehensive master creep testing matrix for Alloy 709 Code Case testing to support the qualification of Alloy 709 is being carried out at ANL, INL, and ORNL. A staged approach to qualify A709 will be 
used to incrementally increase the design-life from $100,000 \mathrm{~h}$ to $300,000 \mathrm{~h}$ and finally $500,000 \mathrm{~h}$ through a series of Code Cases.

The creep Code Case testing matrix is closely monitored. The matrix is revised as needed when new information from ruptured tests becomes available. Table 2 summarizes the creep Code Case testing matrix, which covers a temperature range of $525-1000^{\circ} \mathrm{C}$ and stress levels of $7-380 \mathrm{MPa}$.

ORNL has been tasked to carry out a subset of the creep Code Case testing matrix. The testing procedure followed ASTM E 139-11, Standard Test Methods for Conducting Creep, Creep-Rupture, and StressRupture Tests of Metallic Materials (ASTM 2011). The creep tests were arranged to best utilize the individual creep machine capacity and estimated testing duration. The specimen geometries for creep Code Case testing are shown in Fig. 1. The creep specimen was designed to have a $9.53 \mathrm{~mm}$ gage diameter with a nominal gage length of $47.63 \mathrm{~mm}$. Note that this specimen's gage diameter is larger than the conventional $6.35 \mathrm{~mm}$ diameter creep specimen with the purpose of reducing the oxidation effect by decreasing the surface-to-volume ratio using a larger diameter specimen, to support the very long-term testing. Such specimen design is now used even for short term and intermediate term testing for consistency. All the Code Case testing specimens were machined from the mid-thickness of the Alloy 709 plates along the rolling direction, per ASME test practice.

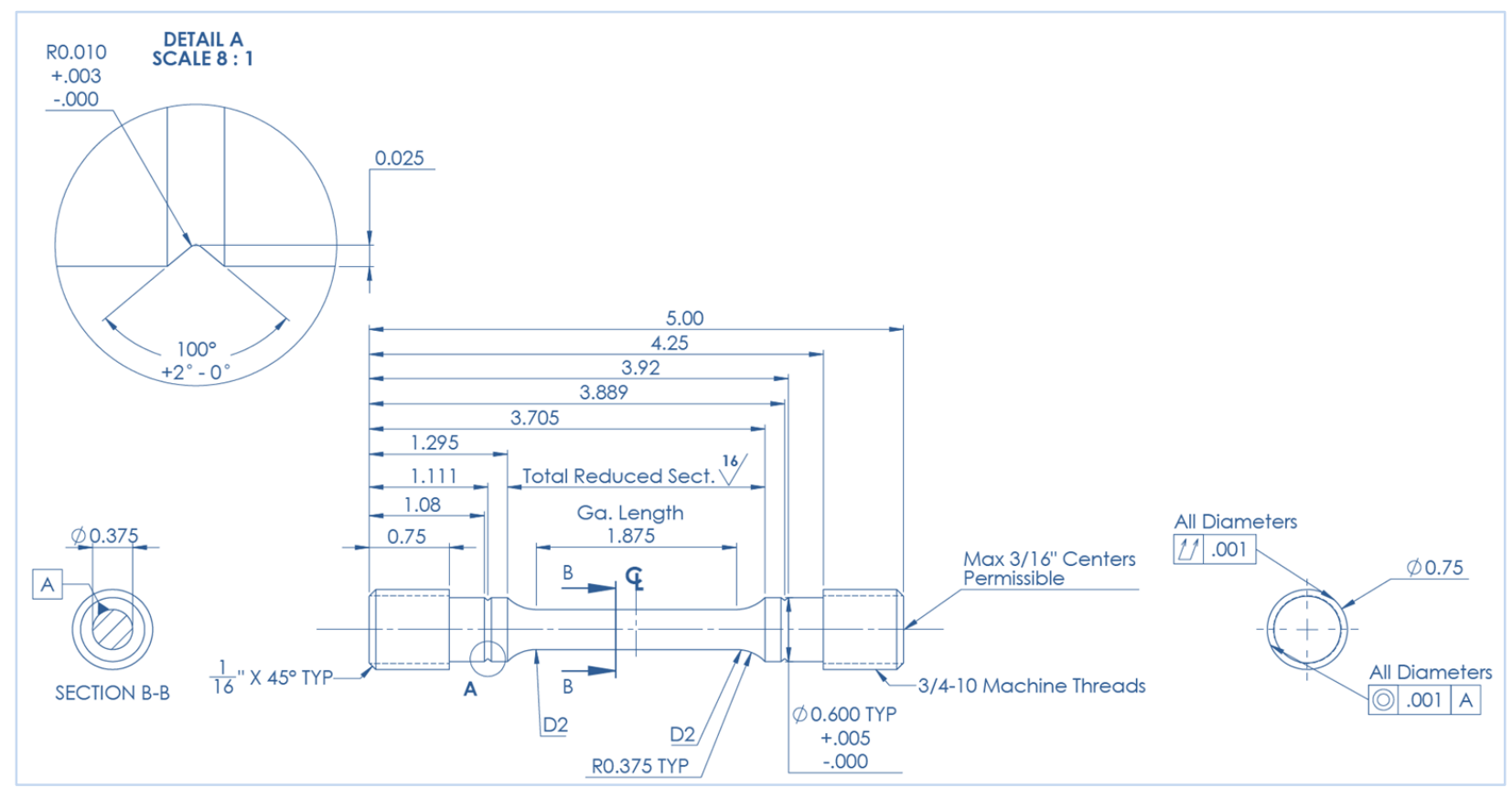

Fig. 1. Creep specimen geometry for Alloy 709 Code Case testing at ORNL. Dimensions are in inches.

In FY 2021, all 24 creep rupture tests on ESR1150-AH tasked to ORNL were started and 6 short-term rupture data were produced. At the time of this report, ongoing creep tests on Alloy 709 base metal at ORNL include 18 on ESR1150-AH, 12 long-term tests on ESR1100, and 4 long-term tests on AOD1100. The ongoing long-term creep Code Case tests on ESR1100 and AOD1100 at ORNL are listed in Table 3, and the testing status of ESR1150-AH at ORNL is summarized in Table 4. 
Table 2. Creep Code Case testing matrix on Alloy 709 (heat number 58776).

\begin{tabular}{c|c|c|c|c|c}
\hline $\begin{array}{c}\text { Target } \\
\text { Code Case }\end{array}$ & $\begin{array}{c}\text { Target rupture life } \\
(\mathbf{h})\end{array}$ & $\begin{array}{c}\text { Temperature } \\
\left({ }^{\circ} \mathbf{C}\right)\end{array}$ & $\begin{array}{c}\text { Stress } \\
(\mathbf{M P a})\end{array}$ & Labs involved & $\begin{array}{c}\text { Materials being tested } \\
\text { at ORNL in FY 2021 }\end{array}$ \\
\hline Preliminary & Up to 11,000 & $600-1000$ & $7-380$ & $\begin{array}{c}\text { ANL/INL/ } \\
\text { ORNL }\end{array}$ & ESR1150-AH \\
\hline $100,000 \mathrm{~h}$ & Up to 25,000 & $575-800$ & $35-330$ & $\begin{array}{c}\text { ANL/INL/ } \\
\text { ORNL }\end{array}$ & $\begin{array}{c}\text { ESR1100; AOD1100 } \\
\text { ESR } 1150-A H\end{array}$ \\
\hline $300,000 \mathrm{~h}$ & Up to 68,000 & $525-800$ & $40-330$ & ORNL & $\begin{array}{c}\text { ESR } 1100 ; \text { AOD1100 } \\
\text { ESR } 1150-A H\end{array}$ \\
\hline $500,000 \mathrm{~h}$ & Up to 110,000 & $525-800$ & $35-355$ & ORNL & $\begin{array}{c}\text { ESR } 1100 ; \text { AOD } 1100 \\
\text { ESR } 1150-A H\end{array}$ \\
\hline
\end{tabular}

Table 3. FY 2021 ongoing creep Code Case testing on ESR1100 and AOD1100 at ORNL.

\begin{tabular}{|c|c|c|c|c|}
\hline $\begin{array}{c}\text { TN } \\
\text { number }\end{array}$ & $\begin{array}{c}\text { Temperature } \\
\left({ }^{\circ} \mathbf{C}\right)\end{array}$ & $\begin{array}{l}\text { Stress } \\
\text { (MPa) }\end{array}$ & Thermocouple & Material \\
\hline 34162 & 525 & 355 & $\mathrm{~K}$ & ESR1100 \\
\hline 34163 & 550 & 330 & $\mathrm{~K}$ & ESR1100 \\
\hline 34182 & 550 & 285 & $\mathrm{~K}$ & ESR1100 \\
\hline 34183 & 575 & 285 & $\mathrm{~K}$ & ESR1100 \\
\hline 34130 & 600 & 200 & $\mathrm{~K}$ & ESR1100 \\
\hline 34113 & 625 & 155 & $\mathrm{~K}$ & ESR1100 \\
\hline 34111 & 700 & 90 & $\mathrm{~K}$ & ESR1100 \\
\hline 34161 & 700 & 80 & $\mathrm{~K}$ & ESR1100 \\
\hline 34112 & 725 & 80 & $\mathrm{~K}$ & ESR1100 \\
\hline 34184 & 750 & 60 & $\mathrm{~K}$ & ESR1100 \\
\hline 34241 & 800 & 40 & $\mathrm{~K}$ & ESR1100 \\
\hline 34265 & 800 & 35 & $\mathrm{~K}$ & ESR1100 \\
\hline 33629 & 550 & 309 & $\mathrm{~K}$ & AOD 1100 \\
\hline 33632 & 700 & 88 & $\mathrm{~K}$ & AOD1100 \\
\hline 33635 & 800 & 38 & $\mathrm{~K}$ & AOD 1100 \\
\hline 33636 & 750 & 58 & $\mathrm{~K}$ & AOD1100 \\
\hline
\end{tabular}


Table 4. FY 2021 creep Code Case testing status on ESR1150-AH at ORNL

\begin{tabular}{|c|c|c|c|c|c|}
\hline $\begin{array}{c}\text { TN } \\
\text { number }\end{array}$ & Target Code Case & $\begin{array}{c}\text { Temperature } \\
\left({ }^{\circ} \mathbf{C}\right)\end{array}$ & $\begin{array}{l}\text { Stress } \\
\text { (MPa) }\end{array}$ & Thermocouple & Status \\
\hline TN39478 & $500,000 \mathrm{~h} \mathrm{CC}$ & 550 & 250 & K & Running \\
\hline TN39346 & 500,000 h CC & 575 & 200 & K & Running \\
\hline TN39344 & 500,000 h CC & 675 & 82 & K & Running \\
\hline TN39345 & 300,000 h CC & 600 & 175 & K & Running \\
\hline TN39368 & $300,000 \mathrm{~h} \mathrm{CC}$ & 625 & 140 & K & Running \\
\hline TN39369 & 300,000 h CC & 750 & 45 & $S$ & Running \\
\hline TN39370 & $100,000 \mathrm{~h} \mathrm{CC}$ & 800 & 35 & $S$ & Running \\
\hline TN38992 & 100,000 h CC & 700 & 90 & K & Running \\
\hline TN39517 & preliminary $\mathrm{CC}$ & 850 & 30 & $S$ & Running \\
\hline TN39518 & preliminary $\mathrm{CC}$ & 875 & 30 & K & Running \\
\hline TN39519 & preliminary $\mathrm{CC}$ & 900 & 30 & K & Ruptured \\
\hline TN39694 & preliminary $\mathrm{CC}$ & 875 & 24 & $S$ & Running \\
\hline TN39513 & preliminary $\mathrm{CC}$ & 900 & 24 & $S$ & Ruptured \\
\hline TN39501 & preliminary $\mathrm{CC}$ & 925 & 24 & $S$ & Ruptured \\
\hline TN39693 & preliminary $\mathrm{CC}$ & 900 & 20 & $S$ & Running \\
\hline TN39511 & preliminary CC & 925 & 20 & $S$ & Ruptured \\
\hline TN39612 & preliminary $\mathrm{CC}$ & 950 & 20 & $S$ & Ruptured \\
\hline TN39842 & preliminary CC & 925 & 15 & $\mathrm{~S}$ & Running \\
\hline TN39692 & preliminary $\mathrm{CC}$ & 950 & 15 & $S$ & Running \\
\hline TN39512 & preliminary CC & 975 & 15 & $S$ & Ruptured \\
\hline TN39843 & preliminary $\mathrm{CC}$ & 975 & 11 & $S$ & Running \\
\hline TN40008 & preliminary $\mathrm{CC}$ & 1000 & 10 & $S$ & Running \\
\hline TN40007 & preliminary CC & 1000 & 7 & $\mathrm{~S}$ & Running \\
\hline TN39910 & preliminary $\mathrm{CC}$ & 975 & 15 & $S$ & Running \\
\hline
\end{tabular}




\subsection{CREEP RUPTURE TEST RESULTS ON ALLOY 709}

For comparison purposes, the Larson-Miller Parameter (LMP) was used to compare all the available creep rupture results on ESR1100, AOD1100, ESR1150, and ESR1150-AH from ORNL, INL and ANL, along with the Nippon Steel NF709 data. The results are shown in Fig. 2. Creep rupture data on ESR1150-AH produced at ORNL in FY 2021 are highlighted with solid symbols. In this plot, the LarsonMiller equation for calculating the LMP was based on Eq. (1):

$$
L M P=(\text { temperature }+273.15) *\left(C+\log \left(t_{r}\right)\right),
$$

where temperate is in ${ }^{\circ} \mathrm{C}$ and rupture life, $t_{r}$, is in hours, and $C$ is assumed to be a constant value of 15 .

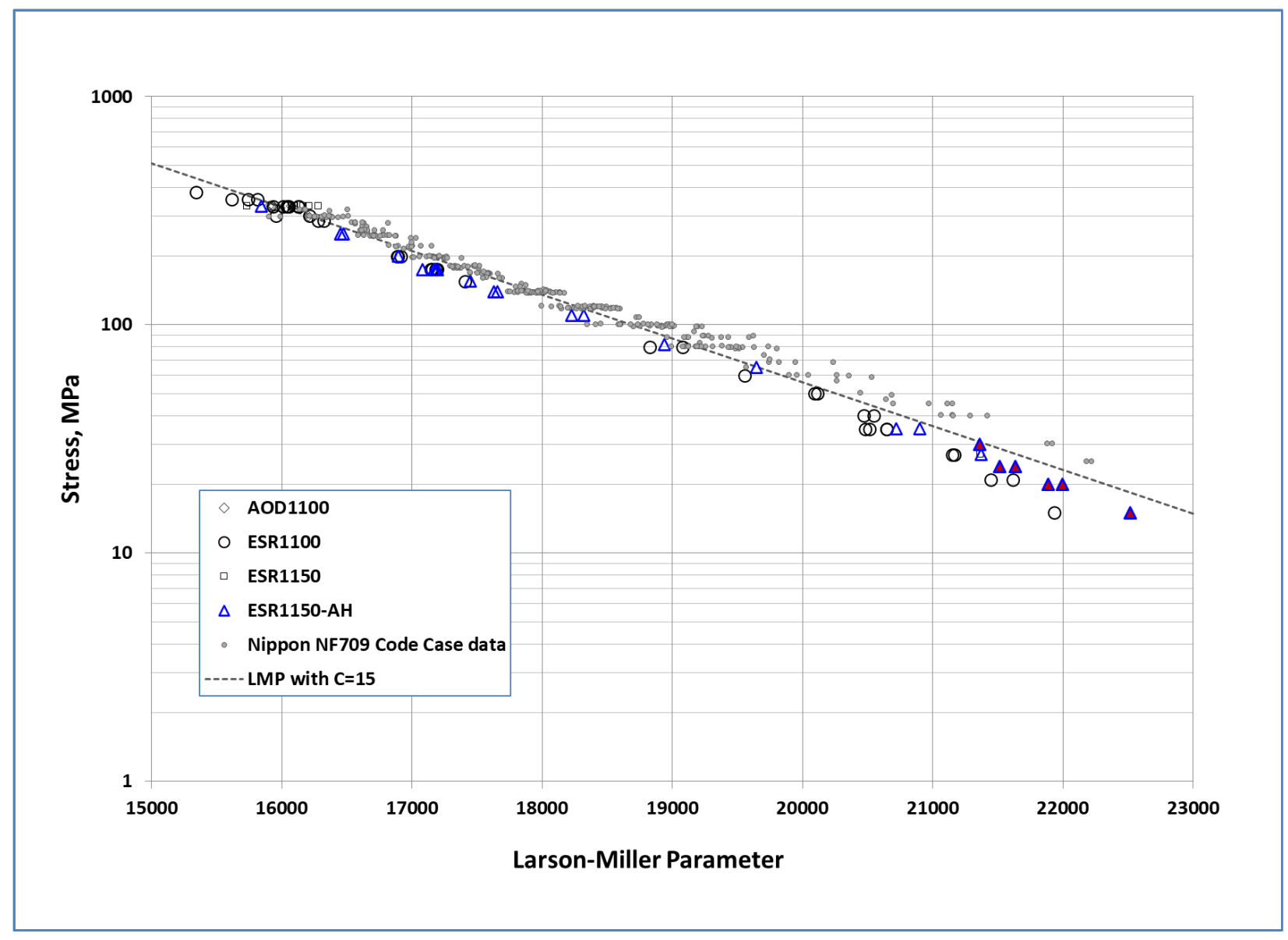

Fig. 2. Comparison of the ESR 1100, AOD1100, ESR1150, and ESR1150-AH creep rupture data with data for Nippon Steel NF709 on the LMP-stress plot.

The results show that this first commercial heat is slightly weaker than Nippon Steel NF709 in terms of creep resistance, since all data points are to the left of those for Nippon Steel NF709, especially at the higher LMP values above 19,000. However, the creep strengths are still significantly higher than the reference material, Type 316 stainless steel. Additional rupture data are needed to fully assess the creep resistance of this first commercial heat of Alloy 709. 


\section{FATIGUE AND CREEP-FATIGUE CODE CASE TESTING ON ALLOY 709}

\subsection{FATIGUE AND CREEP-FATIGUE TESTING}

To be consistent with testing program conventions, the fatigue and $\mathrm{CF}$ testing temperatures were based on US customary units, and testing was conducted at temperatures of $1200^{\circ} \mathrm{F}\left(649^{\circ} \mathrm{C}\right), 1300^{\circ} \mathrm{F}\left(704^{\circ} \mathrm{C}\right)$, $1400^{\circ} \mathrm{F}\left(760^{\circ} \mathrm{C}\right)$, and $1500^{\circ} \mathrm{F}\left(816^{\circ} \mathrm{C}\right)$. The fatigue Code Case testing matrix in support of generating temperature-dependent fatigue design curves for Alloy 709 was developed, and the plan is to generate fatigue design curves up to the maximum testing temperature of $1500^{\circ} \mathrm{F}\left(816^{\circ} \mathrm{C}\right)$ (Wang and Sham 2019). In FY 2020, a preliminary fatigue design curve was developed at $1400^{\circ} \mathrm{F}\left(760^{\circ} \mathrm{C}\right)$, based on fatigue results for ESR1100 and ESR1150-AH (Wang et al. 2020); and the results showed that the fatigue design curve of Alloy 709 was comparable to that of Alloy $800 \mathrm{H}$ at the same temperature. In FY 2021, fatigue testing at a maximum temperature of $1500^{\circ} \mathrm{F}\left(816^{\circ} \mathrm{C}\right)$ was prioritized and tasked to INL, and fatigue testing at $1300^{\circ} \mathrm{F}\left(704^{\circ} \mathrm{C}\right)$ on ESR $1150-\mathrm{AH}$ was initiated at ORNL. In addition, standard CF Code Case testing was started at temperatures of $1200^{\circ} \mathrm{F}, 1300^{\circ} \mathrm{F}, 1400^{\circ} \mathrm{F}$, and $1500^{\circ} \mathrm{F}$ on ESR1150-AH at ORNL and INL to generate data in developing the CF damage interaction diagram.

The specimen geometries for fatigue or CF are shown in Fig. 3. The specimen has a gage diameter of $6.35 \mathrm{~mm}$ and a $19.05 \mathrm{~mm}$ gage length. All the Code Case testing specimens were machined from the midthickness of the Alloy 709 plates along the rolling direction. The fatigue testing followed the ASTM E606-12 standard (ASTM 2012) for conducting strain-controlled fatigue tests, and the CF testing followed the ASTM E2714-13 standard (ASTM 2013) under strain-controlled mode.

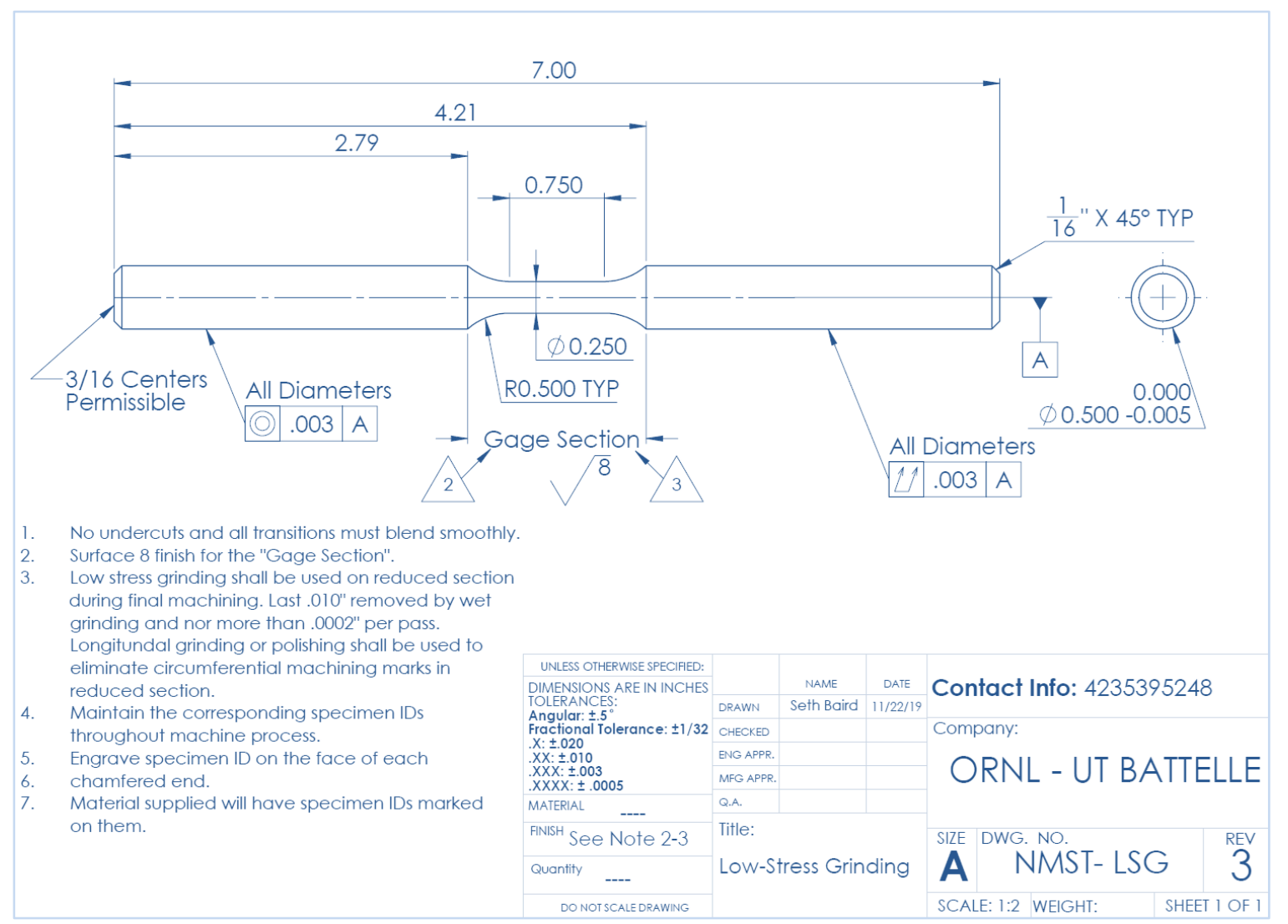

Fig. 3. Standard fatigue and creep-fatigue specimen geometry for Alloy 709 Code Case testing at ORNL. Dimensions are in inches. 
The loading profiles for pure fatigue and CF are shown schematically in Fig. 4. The hold-time segment is applied to the maximum tension amplitude for CF testing. The loading profiles are fully reversed profile, i.e., with a nominal loading ratio of $\mathrm{R}=-1$. The nominal strain rate is $1 \mathrm{E}-3 / \mathrm{s}$ unless otherwise noted. The control extensometer has a nominal gage length of $12.7 \mathrm{~mm}$.

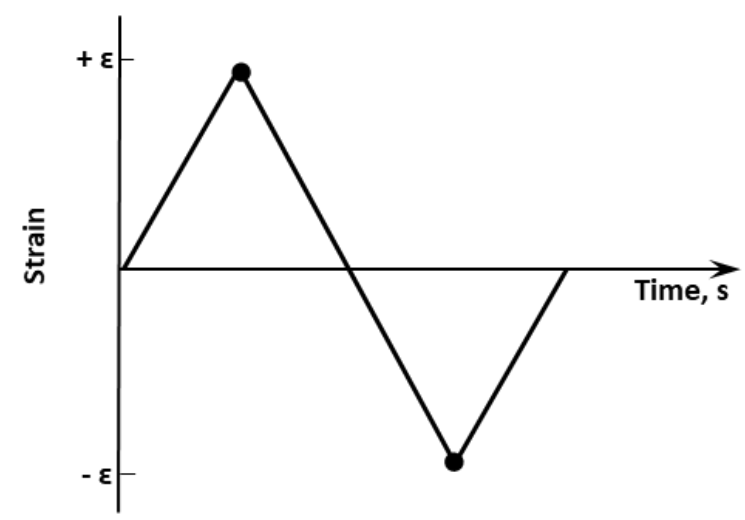

(a)

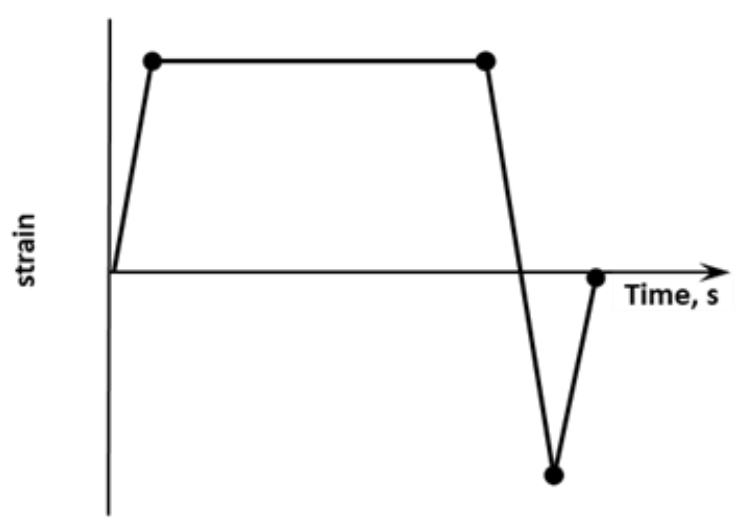

(b)

Fig. 4. Strain-controlled fatigue (a) and creep-fatigue (b) loading profile for one cycle.

\subsection{FATIGUE TEST RESULTS ON ESR1150-AH AT $1300^{\circ} \mathrm{F}$}

Fatigue Code Case testing on ESR 1150 -AH was initiated at $1300^{\circ} \mathrm{F}\left(704^{\circ} \mathrm{C}\right)$, and failure data were generated at strain ranges of $1.0 \%, 0.6 \%$ and $0.3 \%$ at strain rate of $1 \mathrm{E}-3 / \mathrm{s}$. In addition, because the material was responding elastically at the low strain range of $0.2 \%$ at this test temperature, the test was switched to load-controlled mode at an equivalent stress amplitude with a higher frequency of approximately $3 \mathrm{~Hz}$ to speed up the testing.

The maximum and minimum stresses as a function of the applied cycles of these fatigue tests are plotted in Fig. 5. Cyclic hardening behavior was observed at the very beginnings of the applied cycles for all the fatigue tests at the strain ranges presented, and the maximum and minimum stress levels remained saturated until the onset of failure initiation.

The fatigue testing parameters and the cycles to failure are summarized in Table 5. The failure criteria based on the $25 \%$ maximum load drop were used to determine the cycles to failure. Fatigue testing at a $0.2 \%$ strain range had a runout $20,000,000$ cycles and the test was interrupted without failure. 

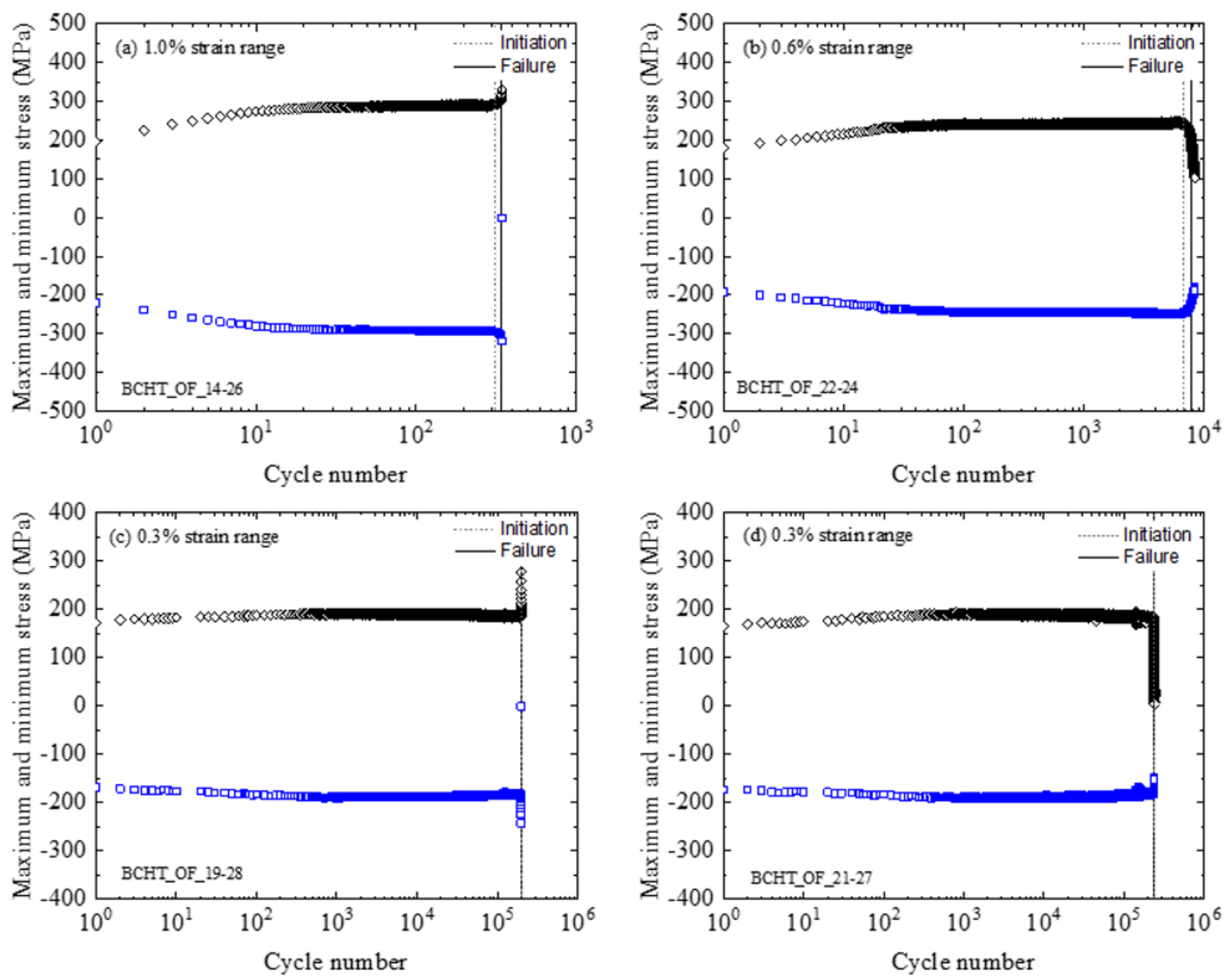

Fig. 5. Maximum and minimum stresses of fatigue tests on Alloy 709 ESR 1150-AH (heat number 58776$3 R B C)$ at strain ranges of $1.0 \%(a), 0.6 \%(b)$, and two tests at $0.3 \%(c, d)$ at $1300^{\circ} \mathrm{F}$.

Table 5. Fatigue test results of ESR 1150 -AH (heat number 58776-3RBC) at $1300^{\circ} \mathrm{F}$.

\begin{tabular}{c|c|c}
\hline Specimen ID & $\begin{array}{c}\text { Strain range } \\
(\boldsymbol{\%})\end{array}$ & Cycles to failure* $^{*}$ \\
\hline BCHT_OF_14_26 & 1.0 & $343^{* *}$ \\
\hline BCHT_OF_22_24 & 0.6 & 7,948 \\
\hline BCHT_OF_19_28 & 0.3 & $197,917^{* *}$ \\
\hline BCHT_OF_21_27 & 0.3 & 238,691 \\
\hline 204D_DX_33 & 0.2 & $>20,000,000 \dagger$ \\
\hline
\end{tabular}

*Failure criteria: $25 \%$ maximum load drop.

** Failure location was outside the extensometer gage.

$\dagger$ The test was performed under load-controlled mode. The specimen did not fail at 20,000,000 cycles 


\subsection{CREEP-FATIGUE TEST RESULTS ON ESR1150-AH}

\subsubsection{Creep-fatigue Results at $1200^{\circ} \mathrm{F}$}

The hold time effect was evaluated on ESR $1150-\mathrm{AH}$ at $1200^{\circ} \mathrm{F}$ at a nominal strain range of $1.0 \%$. Figure 6 presents the evolution of maximum/minimum stresses, representative hysteresis loops, and normalized stress relaxation curves of representative cycles during the tension-hold segment for specimens tested with tension-hold times of $3600 \mathrm{~s}, 1800 \mathrm{~s}$, and $600 \mathrm{~s}$, respectively. Note that the third cycle was plotted to represent the beginning of the cyclic loading because of the noise in the first two cycles for strain-controlled tests. The stress relaxation curves were normalized by the stress value at the beginning of the hold time segment of the cycle of interest. The CF testing condition and the results are summarized in Table 6 . The CF life decreased slightly from 780 cycles to 575 cycles as the holding time increased from $600 \mathrm{~s}$ to $3600 \mathrm{~s}$.

In all cases, cyclic hardening behaviors were observed during the initial 50 applied cycles, as indicated by the increasing maximum and minimum stresses with more applied cycles. After the initial hardening, the material remained cyclic neutral for the remaining applied cycles till failure initiation. As shown in the plots, stress relaxation occurs owing to creep deformation during the tension-hold segment, and the stresses relaxed more rapidly at the mid-life cycle than at the beginning of the fatigue cycles.
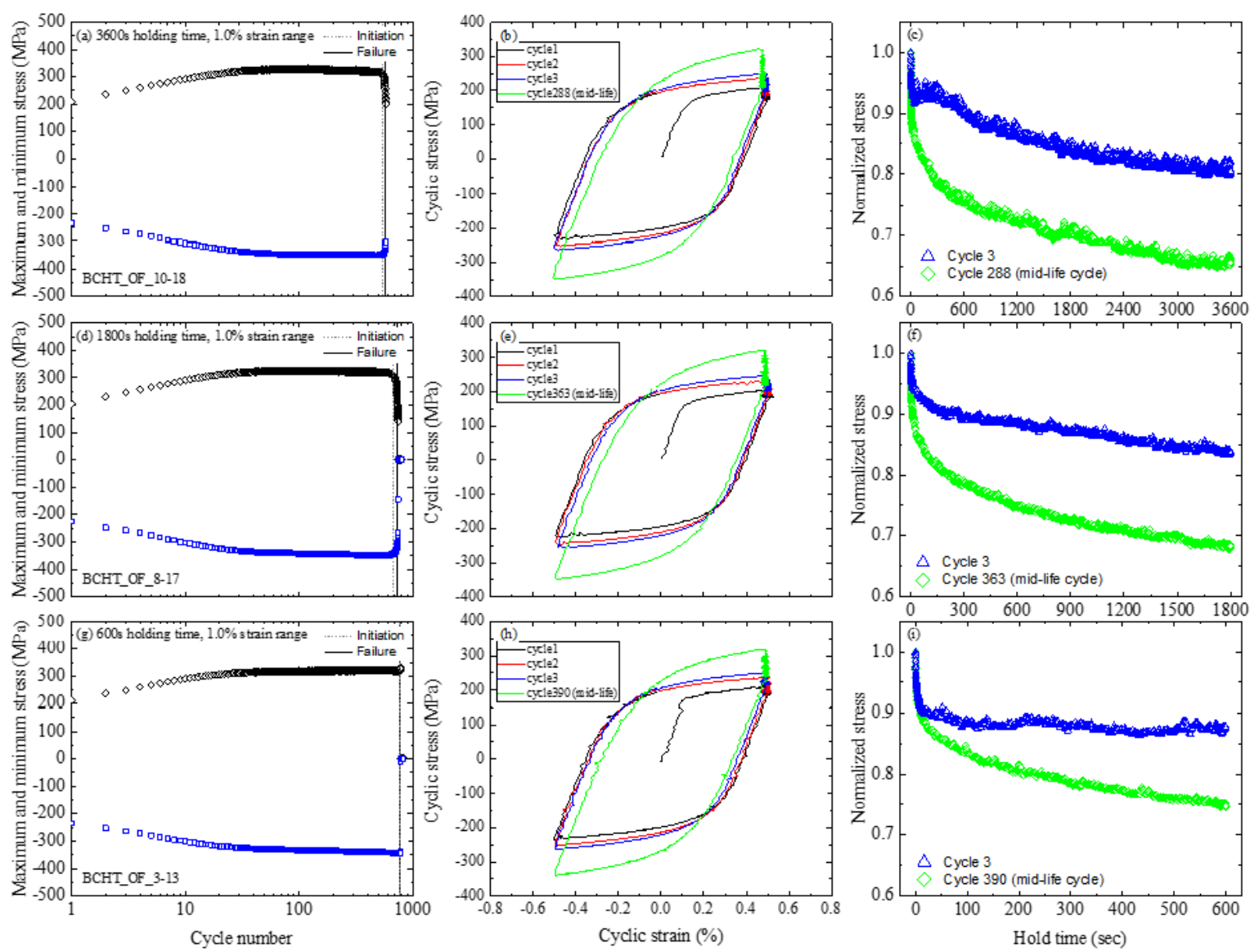

Fig. 6. Maximum and minimum stresses as a function of applied cycles $(\mathrm{a}, \mathrm{d}, \mathrm{g})$; representative hysteresis loops $(b, e, h)$; and normalized stress relaxation curves $(c, f, i)$ for $\mathbf{C F}$ at $1.0 \%$ strain range and tension-hold times of $3600 \mathrm{~s}, 1800 \mathrm{~s}$, and $600 \mathrm{~s}$ at $1200^{\circ} \mathrm{F}$. 
The stresses during the hold segment at the mid-life cycle rapidly decreased with an approximately $20 \%$ in the initial $300 \mathrm{~s}$ of the hold for all three cases and gradually slowed down for the remaining time of the hold segment. The normalized stress relaxation curves of mid-life cycle are compared in Fig. 7 to assess the influence of hold time on stress relaxation behavior. Interestingly, the mid-life stress relaxation behavior showed insignificant differences between the three tests with different hold times at this strain range of $1 \%$ at $1200^{\circ} \mathrm{F}$.

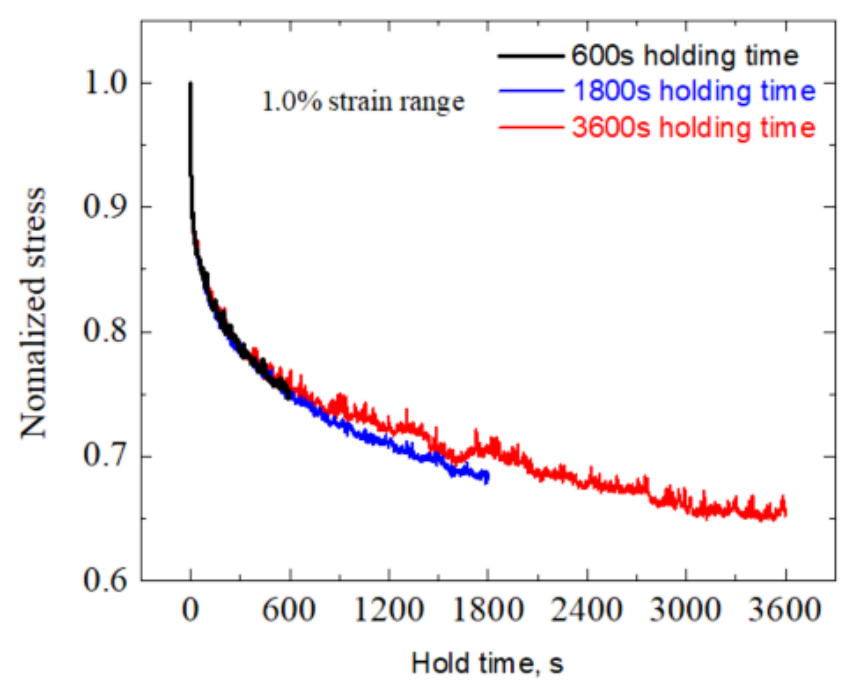

Fig. 7. Comparison of the stress relaxation curves during tension-hold segments at mid-life cycles between $600 \mathrm{~s}, 1800 \mathrm{~s}$, and $3600 \mathrm{~s}$ hold times at a $1.0 \%$ strain range at $1200^{\circ} \mathrm{F}$.

Table 6. Summary of the CF results for ESR1150-AH at $1200^{\circ} \mathrm{F}$.

\begin{tabular}{l|l|l|l}
\hline Specimen ID & Strain range, \% & $\begin{array}{l}\text { Tension holding } \\
\text { time, s }\end{array}$ & $\begin{array}{l}\text { Cycles to } \\
\text { failure }\end{array}$ \\
\hline BCHT_OF_10-18 & 1.00 & 3,600 & 575 \\
\hline BCHT_OF_8-17 & 1.01 & 1,800 & 726 \\
\hline BCHT_OF_3-13* & 1.01 & 600 & 780 \\
\hline
\end{tabular}

* Failed outside the extensometer gage

$\dagger$ Failure criteria: $25 \%$ maximum load drop.

\subsubsection{Creep-fatigue Results at $1400^{\circ} \mathrm{F}$}

Three CF tests were completed on ESR $1150-\mathrm{AH}$ at $1400^{\circ} \mathrm{F}$. The maximum/minimum stresses, representative hysteresis loops, and normalized stress relaxation curves of representative cycles during the tension-hold segment for tests at a nominal strain range of $0.6 \%$ and hold times of $1800 \mathrm{~s}$ and $600 \mathrm{~s}$ are plotted in Fig. 8. The curves for the test at a nominal strain range of $1 \%$ and a hold time of $600 \mathrm{~s}$ are shown in Fig. 9. The CF testing parameters and the results are summarized in Table 7.

Slight cyclic hardening behavior was observed at the beginnings of the applied cycles at this test temperature of $1400^{\circ} \mathrm{F}$. It is evident that the stress relaxation was much faster at this test temperature than at $1200^{\circ} \mathrm{F}$ for similar loading conditions, and there was significant stress relaxation even at the beginnings of the applied cycles. Additional applied cycles did not significantly enhance the stress relaxation rate, as shown by the comparison of the stress relaxation curves at the mid-life cycle and the third cycle. 

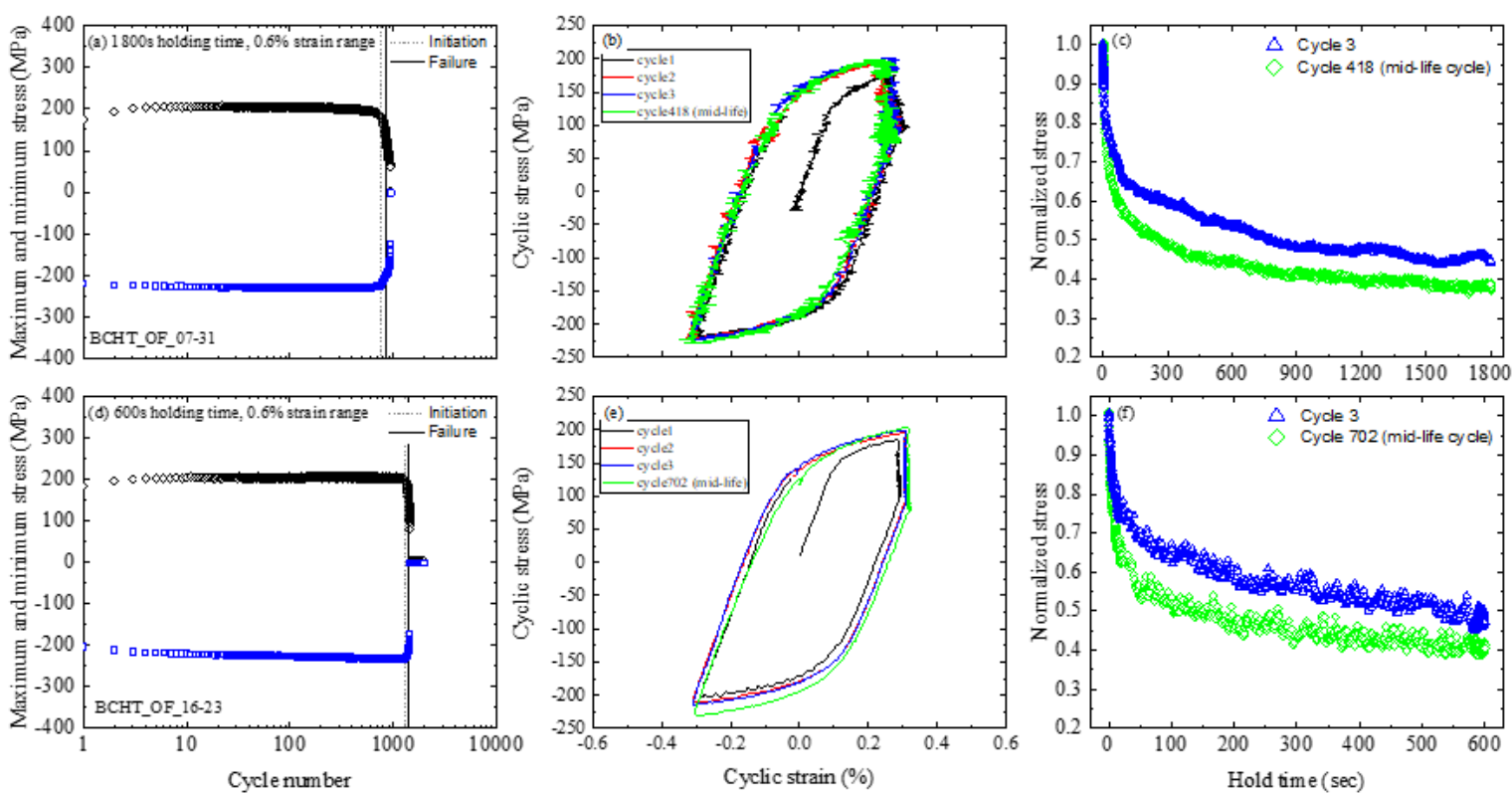

Fig. 8. Maximum and minimum stresses as a function of applied cycles (a, d), representative hysteresis loops $(b, e)$, and normalized stress relaxation curves (c, f) for $\mathrm{CF}$ at a $0.6 \%$ strain range and tension-hold times of $1800 \mathrm{~s}$ and $600 \mathrm{~s}$ at $1400^{\circ} \mathrm{F}$.
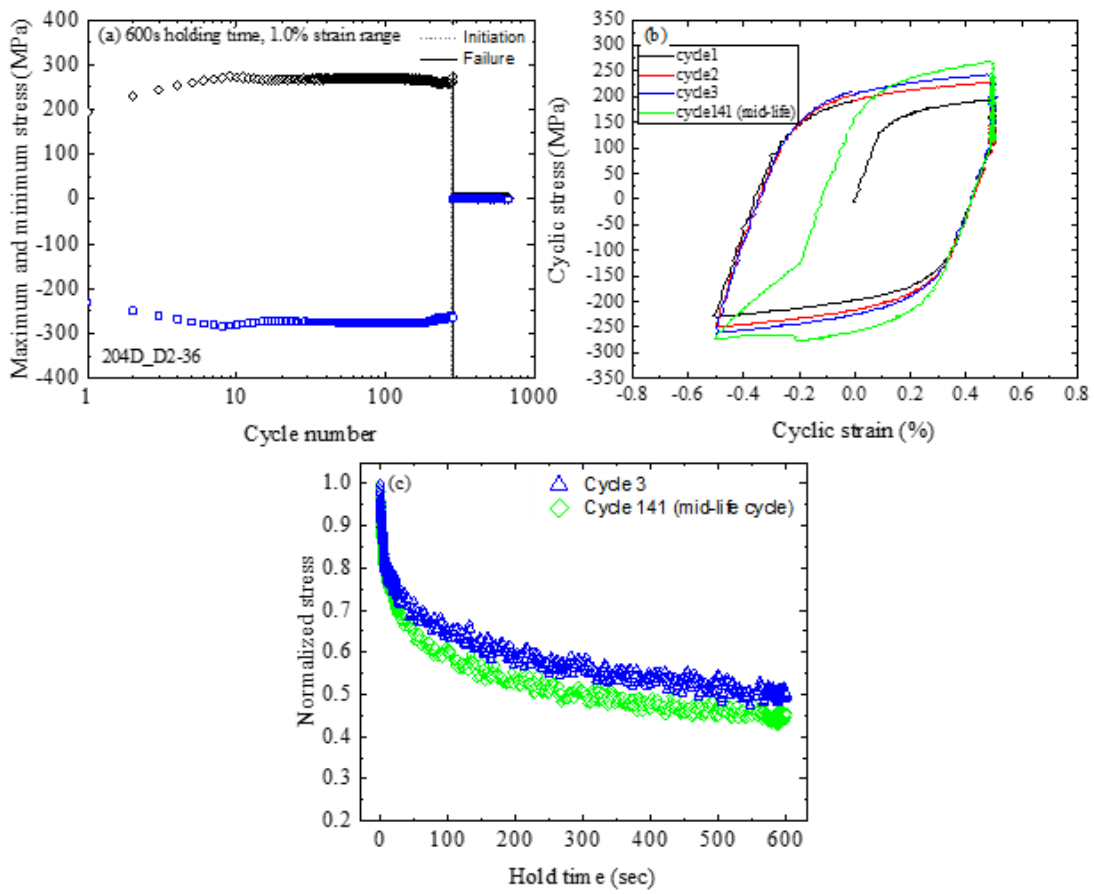

Fig. 9. Maximum and minimum stresses as a function of applied cycles (a), representative hysteresis loops (b), and normalized stress relaxation curves (c) for $\mathrm{CF}$ at a $1.0 \%$ strain range and a tension-hold time of $600 \mathrm{~s}$ at $1400^{\circ} \mathrm{F}$. 
The CF results were also plotted on the previously developed preliminary fatigue best-fit curve at $1400^{\circ} \mathrm{F}$ shown in Fig. 7. The influence of the $600 \mathrm{~s}$ tension-hold time on the reduction of the failure cycles was similar at these two strain ranges of $1 \%$ and $0.6 \%$. Duplicates and additional CF tests at different strain ranges and hold times are ongoing to obtain a complete understanding of the hold time effect, and to provide the required failure data for developing the $\mathrm{CF}$ interaction damage diagram.

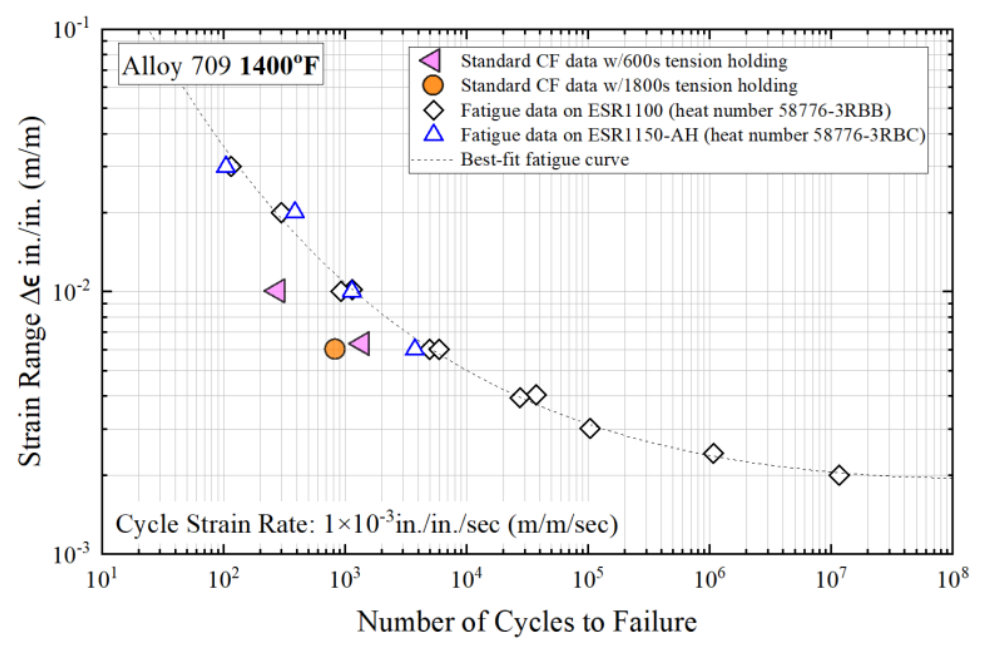

Fig. 10. Fatigue and creep-fatigue data at $1400^{\circ} \mathrm{F}$.

Table 7. Summary of the CF results on ESR $1150-\mathrm{AH}$ at $1400^{\circ} \mathrm{F}$.

\begin{tabular}{l|l|l|l}
\hline Specimen ID & Strain range, \% & Tension holding time, $\mathbf{s}$ & Cycles to failure $\dagger$ \\
\hline 204D_D2-36 & 1.01 & 600 & 282 \\
\hline BCHT_OF_07-31 & 0.62 & 1,800 & 835 \\
\hline BCHT_OF_16-23 & 0.61 & 600 & 1,404 \\
\hline
\end{tabular}

$\dagger$ Failure criteria: $25 \%$ maximum load drop.

\subsubsection{Creep-fatigue Results at $1500^{\circ} \mathrm{F}$}

Seven standard $\mathrm{CF}$ tests were completed at $1500^{\circ} \mathrm{F}$ at the nominal strain ranges of $1.0 \%, 0.6 \%$, and $0.3 \%$ with various tension-hold times. The maximum/minimum stresses, representative hysteresis loops, and normalized stress relaxation curves of representative cycles during the tension-hold segment for tests at a nominal strain range of $1.0 \%$ are plotted in Fig. 11, and the curves for tests at a nominal strain range of $0.6 \%$ are shown in Fig. 12. The normalized mid-life stress relaxation curves for tests at both $1.0 \%$ and $0.6 \%$ strain ranges are compared in Fig. 13. Plots of the CF test performed at a low strain range of $0.3 \%$ and a $600 \mathrm{~s}$ tension hold are shown in Fig. 14. A summary of the CF testing parameters and the results is in Table 8.

The results show that at both higher strain ranges of $1.0 \%$ and $0.6 \%$, the material showed the highest stress relaxation rates compared with the tests performed under the same loading conditions at lower test temperatures. The stresses relaxed by $50 \%$ to $60 \%$ during the $600 \mathrm{~s}$ hold time at the peak tension amplitude. At $1500^{\circ} \mathrm{F}$ and higher strain ranges of $1.0 \%$ and $0.6 \%$, the material showed the same stress relaxation behavior at the beginning of the test and at the mid-life cycle, with overlapping normalized 
stress relaxation curves, except for one test at $0.6 \%$ with a $600 \mathrm{~s}$ hold time. The normalized mid-life stress relaxation curves at both the $1.0 \%$ and $0.6 \%$ strain ranges in Fig. 13 show that at longer holding times of $1800 \mathrm{~s}$ and $3600 \mathrm{~s}$, the stress realxation behavior is almost identical and is slower than that with shorter hold time of $600 \mathrm{~s}$, indicating the same CF damage mechnism at these two longer hold times at these strain ranges in this study.

At a $1.0 \%$ strain range at $1500^{\circ} \mathrm{F}$, the increase in the tension-hold time from $600 \mathrm{~s}$ to $3600 \mathrm{~s}$ did not affect the cycles to failure significantly. At a $0.6 \%$ strain range, the cycles to failure were reduced when the hold time increased from $600 \mathrm{~s}$ to $1800 \mathrm{~s}$; but the hold time effect is not clear when it is further increased to $3600 \mathrm{~s}$, based on the available data.

At a low strain range of $0.3 \%$ with a $600 \mathrm{~s}$ tension-hold time (Fig. 14), comparing the stress relaxation curves at the beginning of the test and at the mid-life cycle with those at higher strain ranges, the stress relaxation was much slower than at higher strain ranges.

Note that the plan is to duplicate all the tests reported to obtain a clearer understanding of the data scatter and the repeatability of the $\mathrm{CF}$ tests under the same conditions. Conventionally, three repeats are performed with the same testing parameters.
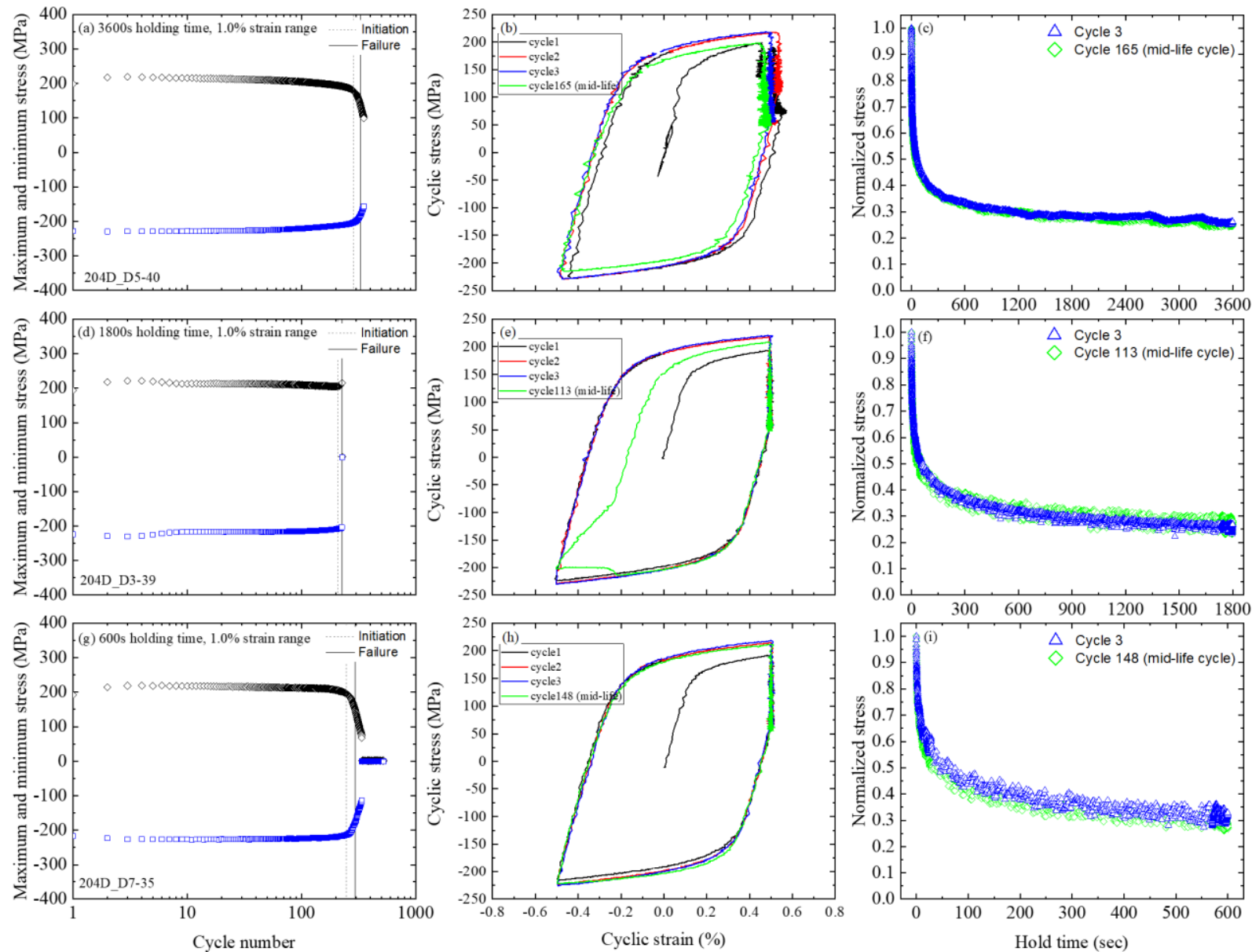

Fig. 11. Maximum and minimum stresses as a function of applied cycles $(\mathrm{a}, \mathrm{d}, \mathrm{g})$, representative hysteresis loops $(\mathrm{b}, \mathrm{e}, \mathrm{h})$, and normalized stress relaxation curves $(\mathrm{c}, \mathrm{f}, \mathrm{i})$ for $\mathrm{CF}$ at a $1.0 \%$ strain range and tension-hold times of $3600 \mathrm{~s}, 1800 \mathrm{~s}$, and $600 \mathrm{~s}$ at $1500^{\circ} \mathrm{F}$. 

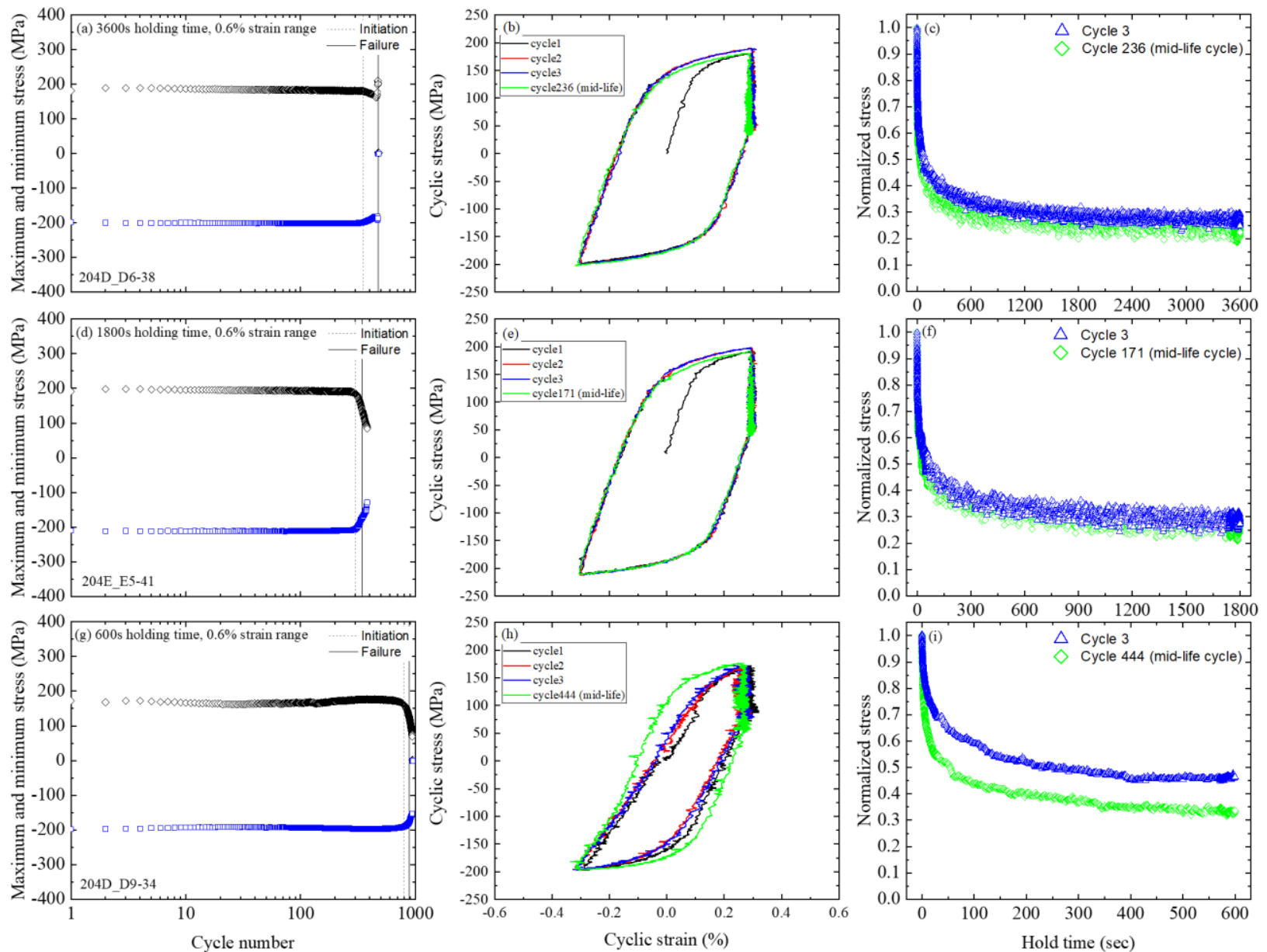

Fig. 12. Maximum and minimum stresses as a function of applied cycles $(a, d, g)$, representative hysteresis loops $(\mathrm{b}, \mathrm{e}, \mathrm{h})$, and normalized stress relaxation curves $(\mathrm{c}, \mathrm{f}$, (i) for $\mathrm{CF}$ at a $0.6 \%$ strain range and tension-hold times of $3600 \mathrm{~s}, 1800 \mathrm{~s}$, and $600 \mathrm{~s}$ at $1500^{\circ} \mathrm{F}$.
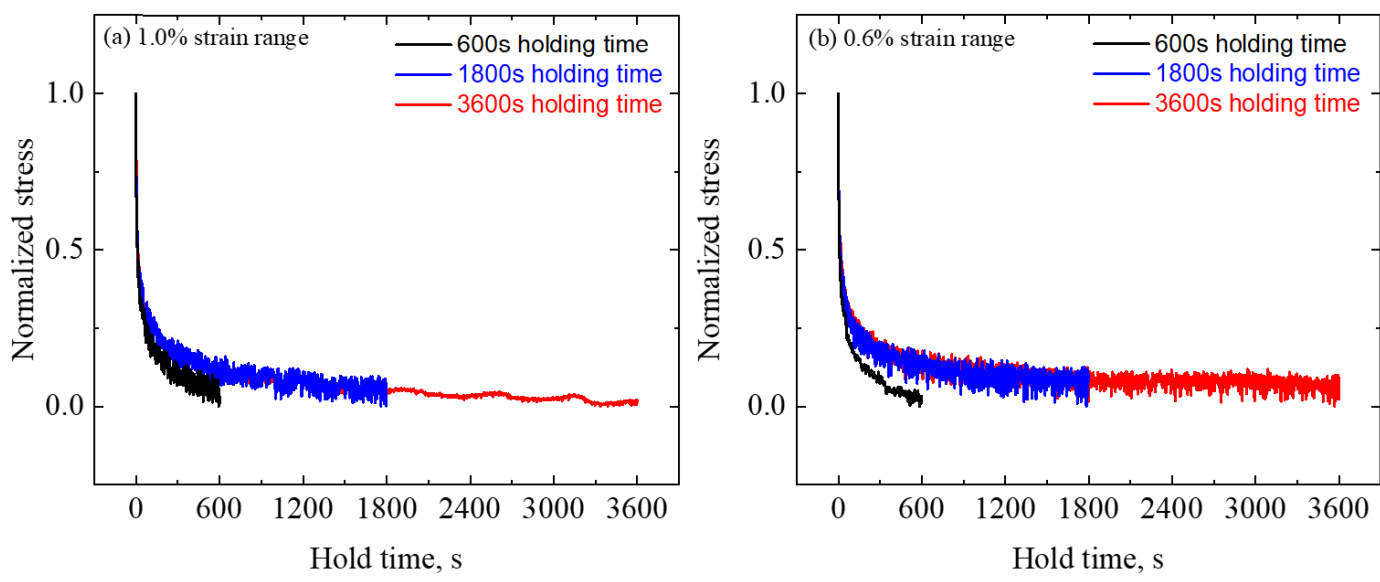

Fig. 13. Comparison of stress relaxation curves during tension-hold at mid-life cycles for $\mathrm{CF}$ tests at strain ranges of $1.0 \%$ (a) and $0.6 \%$ (b) at $1500^{\circ} \mathrm{F}$. 

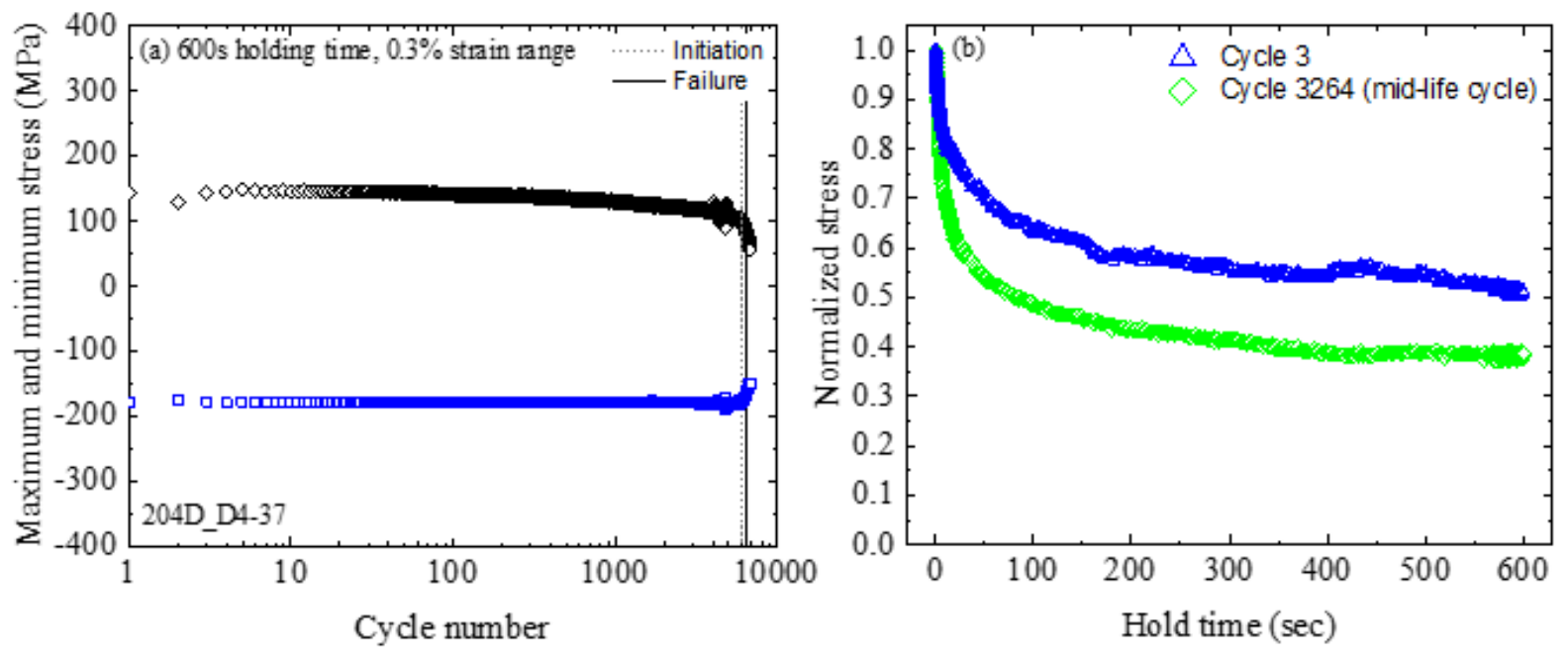

Fig. 14. Maximum and minimum stresses as a function of applied cycles (a) and normalized stress relaxation curves (b) for $\mathrm{CF}$ at a $0.3 \%$ strain range and a tension-hold time of $600 \mathrm{~s}$ at $1500^{\circ} \mathrm{F}$.

Table 8. Summary of the CF results on ESR $1150-\mathrm{AH}$ at $1500^{\circ} \mathrm{F}$.

\begin{tabular}{l|l|l|l}
\hline Specimen ID & Strain range, \% & $\begin{array}{l}\text { Tension holding } \\
\text { time, s }\end{array}$ & Cycles to failure \\
\hline 204D_D5-40 & 0.99 & 3,600 & 330 \\
\hline 204D_D3-39 & 1.02 & 1,800 & 226 \\
\hline 204D_D7-35 & 1.01 & 600 & 296 \\
\hline 204D_D6-38 & 0.62 & 3,600 & 472 \\
\hline 204E_E5-41 & 0.62 & 1,800 & 342 \\
\hline 204D_D9-34 & 0.62 & 600 & 887 \\
\hline 204D_D4-37 & 0.32 & 600 & 6,528 \\
\hline
\end{tabular}

\section{SUMMARY}

The results from the planned FY 2021 Code Case testing at ORNL in support of the ASME code qualification of Alloy 709 are summarized in this report. A subset of the creep Code Case testing matrix on ESR1150-AH with 24 testing conditions tasked to ORNL were started, and 6 short-term rupture data were produced. At the time of this report, ongoing creep tests of the Alloy 709 base metal at ORNL include 18 tests on ESR1150-AH, 12 long-term tests on ESR1100 and 4 long-term tests on AOD1100. Fatigue and CF Code Case testing continued. Preliminary fatigue test results were produced at $1300^{\circ} \mathrm{F}$; $\mathrm{CF}$ testing was initiated at $1200^{\circ} \mathrm{F}, 1400^{\circ} \mathrm{F}$, and $1500^{\circ} \mathrm{F}$, and $\mathrm{CF}$ failure data were generated at various strain ranges and hold times.

Creep, fatigue, and CF experiments in support of the ASME code qualification of Alloy 709 will continue in FY 2022 at ORNL. 


\section{REFERENCES}

ASME (2019a), Standard Specification for Seamless Ferritic and Austenitic Alloy-Steel Boiler, Superheater, and Heat-Exchanger Tubes, ASME Boiler and Pressure Vessel Code, Section II Materials, American Society of Mechanical Engineers, New York, NY (2019 Edition).

ASTM (2011), Standard Test Methods for Conducting Creep, Creep-Rupture, and Stress-Rupture Tests of Metallic Materials, ASTM E 139-11, ASTM International, West Conshohocken, PA, www.astm.org

ASTM (2012), Standard Test Method for Strain-Controlled Fatigue Testing, ASTM E606/E606M-12, ASTM International, West Conshohocken, PA, www.astm.org

ASTM (2013), Standard Test Methods for Standard Test Method for Creep-Fatigue Testing, ASTM E2714-13, ASTM International, West Conshohocken, PA, www.astm.org

M. D. McMurtrey and R. Rupp (2019), Report on FY-19 Scoping Creep and Creep-Fatigue Testing on Heat Treated Alloy 709 Base Metal, INL/EXT-19-55502, Idaho National Laboratory, Idaho Falls, ID.

K. Natesan, X. Zhang, T.-L. Sham, and H. Wang (2017), Report on the Completion of the Procurement of the First Heat of Alloy 709, ANL-ART-89, Argonne National Laboratory, Lemont, IL, June 2017.

H. Wang, C. S. Hawkins, E. C. Disney and J. L. Moser (2018), The Initiation of Long-Term Creep Rupture Tests on the First Alloy 709 Commercial Heat, ORNL/TM-2018/985, Oak Ridge National Laboratory, Oak Ridge, TN.

Y. Wang and T.-L. Sham (2019), Planned FY19 Creep and Fatigue Design Curve Testing of Alloy 709 Base Metal, ORNL/TM-2019/1303, Oak Ridge National Laboratory, Oak Ridge, TN.

Y. Wang, P. Hou and T.-L. Sham (2020), Report on FY 2020 Creep, Fatigue, and Creep-Fatigue Testing of Alloy 709 Base Metal at ORNL, ORNL/TM-2020/1622, Oak Ridge National Laboratory, Oak Ridge, TN.

X. Zhang and T.-L. Sham (2019), FY19 Status Report on Creep Test Data on Commercial Heat of Alloy 709, ANL-ART-172, Argonne National Laboratory, Lemont, IL.

X. Zhang, T.-L. Sham and G. A. Young (2019), Microstructural Characterization of Alloy 709 Plate Materials with Additional Heat Treatment Protocol, ANL-ART-170, Argonne National Laboratory, Lemont, IL. 